The very attempt to define "Malay" is abortive. Harrisson invokes religion, habitat and "character". He rejects or omits language and adat (custom); these, as I found in my own work among Malays in Pahang, are quintessential features. In the same context, the recent appearance of Malays in the delta is repeatedly referred to as a sort of pagan percolation, down from the interior through the Islamic conversion-barrier. The seaborne immigration of ready-made Muslims from other parts of the Malay world is glossed over.

As with all scrapbooks, however, there is something deeper. While The Malays of South-West Sarawak fulfils administrative and scholarly obligations, for which we can only bo grateful, there is much in it that concerns the author's friends over the years; it is not only an immediately personal document but also a fond and hopeful farewell to a world he knew.

W. D. WILDER

\section{NEW LOOK AT SOCIAL LIFE}

\section{Social Interaction}

By M. Argyle. (Methuen's Manuals of Modern Psychology.) Pp. 504. (Methuen: London, October 1969.) $75 s$.

Social Interaction is a central concept for social scientists -in management, marriage, psychotherapy and community life. Where social interaction brcaks down, the pathologies of social life flourish and it is therefore essential to understand its elements. Indeed, the diversity of attempts to do so-in anthropology, ethology, psychology, sociology and psychiatry-has given rise to a plethora of studios in a babel of tongues which simultaneously cry out for some kind of integration and arouse apprchension that this is not really possible. The International Encyclopedia of the Social Sciences contains more than fifty review articles on different aspects of the field. Most introductory texts have dealt with the problem of how to cover the ground, either by selecting materials on the basis of a particular theoretical approach (Freud or Sullivan in the psychoanalytic framework; Krech and Krutchfield or Asch in the gestalt psychology framework; Eysenck or Dollard and Miller in the bohaviourist framework), or they have been encyclopaedic and somewhat indigestible (Secord and Backman, or at a more advanced level Gardner Lindzey's Handbook of Social Psychology).

Argyle attempts to deal with the issue of presentation by taking an intcrmediate stance. While he does not present a full-blown thcory or expound his teachings within the framework of one of the established theories, he argues that there is a "new look" in the work of re. searchers in the disparate fields mentioned which both differentiates them from their more conventional colleagues within their disciplines and makes them resemble one another, perhaps more than many appreciate. The new look concentrates on the observable elements on interaction sequences, stressing non-verbal as well as verbal dimensions of behaviour. Posture, eye-contact, eyoball movements, and the like, receive as much attention as actual content of communication. This approach contrasts with somo of the earlicr work which took such attributes as group cohesiveness, leadership style, and so forth, and measured them largely in terms of verbal interaction patterns; correlating these attributes with some group outcome such as task accomplishment. The apthor, however, is well aware of the danger of an over-concentration on elements to the neglect of integrative concepts. Indeed, the main thrust of his work is integrative---with emphasis on contextual factors as seen in various interaction fields.

The author sets forth the elements of the new look in his first three chapters and then in the six chapters that follow presents a review of work in the conventional topic areas-interpersonal perception, two-person relationships, small groups, social organizations and personality. Then, in the three chapters at the end, ho explores the implications, theoretical and applied, of the new ideas and information.

In setting forth the dimensions of the new look in social interaction research, Argyle indubitably performs a valuable service not only for introductory students of social psychology but for a variety of professional colleagues as well. In attempting to organize the existing body of literature in terms of this new look for the purpose of presenting the introductory student with a navigable map of the field, he is less successful. This does not mean that the middle chapters-the meat of Argyle's sandwich-are not intrinsically interesting. His presentation of material on the various dimensions of interaction is formidable, benefiting from his gift for enlivening experimental findings. Only an inveterate (and productive) optimist would have dared to risk attack from all sides for trying too much. His success, however, at integrating the new look into the relevant bodies of literature is rather uneven. The fit is most complete when he reviews his own experimental work in social interaction and that of a few like-minded colleagues in other fields. When, however, he reports earlier work-as he must to provide the coverage needed for a textbook-the fit is less complete.

Also, something is, inevitably, lost by the attempt to emphasize the new look, and this seems to be some of the historical depth which is useful for the student to appreciate in any field of enquiry. Freud's name is lacking from the author index (though many modern derivatives are included) and, perhaps in keeping with the experimental psychological bias of the work generally, there is much less on the social side (no Durkheim, no Marx, no Weber, and only a smattering of George Herbert Mead, though to give the author his due he has quite useful indications of the place of modern derivatives even including Talcott Parsons).

Indeed, nearly everybody who is important in the field of social interaction is mentioned at least somewhere in the book, and located in professional space. On the other hand, some of the mentions are not the best possible for a given topic or for the individual's main contribution (for example, Gorer on bereavement), some are the merest nods to massive bodies of information, and there is quite a lot of use of such secondary materials as Desmond Morris on the sexual life of primitive people.

The book is, however, studded with interesting findings and perspectives, and has the great merit of indicating how different approaches and methods are useful for different kinds of problems - a point of view often sorely lacking amongst some methods. oriented researchers in this field. Indeed, for a person basically brought up as an experimental psychologist and who has a contemporary fascination for eyeball movements, Argyle does a very creditable job of acquaint ing noviccs with the social as well as the psychological side of the interaction process. Alex Inkeles, the Harvard sociologist, once observed, in the course of his studies of Russian national character, that their fascination with the eyes (possibly deriving from the practice of swaddling infants and restricting their capacity to explore the environment by other means) pointed up a possible deficiency of Freudian theory which concentrates perhaps too much on the oral, anal and genital zones. However this may be, Michael Argyle's attitude toward his own novices is anything but that of the swaddler, and he conducts them around to have a new look for themselves at the works of scholars in neighbouring as well as his own vineyard. The book has merits beyond its stated purpose as an introductory text; but for that purpose its success will depend in part on the quality of the teaching that accompanies its use.
R. N. RAPOPORT 